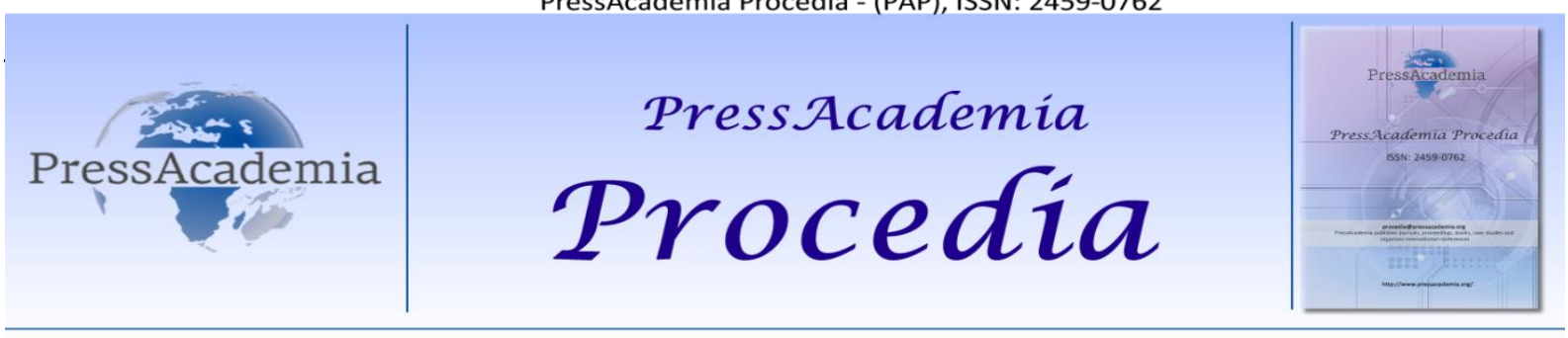

Global Business Research Congress (GBRC), May 24-25, 2017, Istanbul, Turkey.

\title{
AN EMPIRICAL STUDY TO DETERMINE THE E-SHOPPING BEHAVIORS OF CONSUMERS
}

DOI: 10.17261/Pressacademia.2017.413

PAP-GBRC-V.3-2017(28)-p.281-289

\section{Aysegul Ermec Sertoglu, Husniye Ors, Ozlem Catli}

Gazi University, , International Trade Department, Ankara, Turkey. aermec@gazi.edu.tr

Gazi University, International Trade Department, Ankara, Turkey. husniye@gazi.edu.tr

Gazi University, , International Trade Department, Ankara, Turkey. ozlembarel@gazi.edu.tr

To cite this document

Sertoglu, A.E., H. Örs and O. Catli, (2017). An empirical study to determine the e-shopping behaviors of consumers. PressAcademia Procedia (PAP), V.3, p.281-289

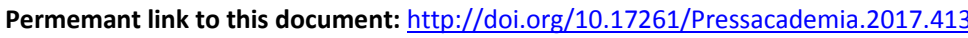

Copyright: Published by PressAcademia and limited licenced re-use rights only.

\begin{abstract}
The purpose of this study is to determine the e-shopping behaviour of consumers and in what stage of the buying decision making process the Internet is used more heavily. It is also aimed to compare online shoppers and in-store shoppers in terms of demographics.Data were collected from a convenience sample of 340 consumers living in Ankara via a survey. Obtained data were submitted to descriptive analysis. The results indicate that the vast majority of consumers shop online. It can be stated that main reason of Internet research (browsing) was to obtain the price information and secondly to examine the comments and suggestions of the users of the product. Mostly searched product group on the Internet is electronic products while the most purchased products are clothes and shoes. It can be said that the characteristics of those who adopt e-shopping are higher income, higher eductaion and being young. The findings show that consumers are actively using the Internet even before the purchasing stage, and Internet research is carried out especially to obtain price information.
\end{abstract}

Keywords: E-shopping, in-store shopping, buying behavior, information searching behavior, internet.

JEL Codes: D10, M30, M31

\section{TÜKETICILERIN E-ALIŞVERIŞE ILIŞKIN DAVRANIŞLARINI ORTAYA KOYMAYA YÖNELIK AMPIRIK BíR ARAŞTIRMA}

\section{ÖZET}

Bu çalışmanın amacı tüketicilerin e-alışveriş davranışlarının belirlenmesi ve İnternet'in satın alma karar sürecinin hangi aşamasında daha yoğun olarak kullanıldığının tespit edilmesidir. Bununla birlikte internetten ve mağazadan alısveriş yapan tüketicilerin demografik özellikler açııından karşılaştırılmaları da amaçlanmaktadır. Veriler, Ankara'da yaşayan 340 tüketiciden oluşan kolayda bir örneklemden anket formu aracılığıyla toplanmıştır. Elde edilen veriler tanımlayıcı analizlere tabi tutulmuştur. Sonuçlar, tüketicilerin büyük bir çoğunluğunun Internet üzerinden alışveriş yaptığını göstermektedir. Ağırlıklı olarak fiyat bilgisi edinmek için Internetten araştırma yapııdığı, ikinci olarak da ürünü kullananların yorum ve önerilerinin incelendiği görülmüştür. Internet üzerinden en çok araştırılan ürün grubu elektronik ürünler olurken, en çok satın alınanlar ise kıyafet-ayakkabı olmuştur. E-alışverişi benimseyenlerin daha çok 18-29 yaş arasındaki, yüksek gelirli, önlisans-lisans mezunu katılımcılar olduğu söylenebilir. Elde edilen bulgular tüketicilerin Internet'in satın alma aşamasından önce de aktif olarak kullandığını, özellikle fiyat bilgisi edinmek için Internet araştırması yapıldı̆̆ını göstermektedir.

Anahtar Kelimeler: E-alışveriş, mağaza içi alışveriş, satın alma davranışı, bilgi araştırma davranışı, internet. JEL Kodları: D10, M30, M31 


\section{GíRiş}

Yeni ekonomide internet kullanıcılarının sayısının ve internet kullanım oranlarının artması ile birlikte Internetin kullanım alanları da artmaktadır. Bu alanlardan biri de e-ticaret ve dolayısıyla e-alışveriştir. İşletmelerin geleneksel kanallarına yoğunlaşan çabalarını çevrimiçi (online) kanalları da kapsayacak şekilde genişletmesi ve çoklu kanal pazarlamasının ortaya çıkması, tüketicilerin bu durum karşısındaki tepkilerinin ve alışveriş alışkanlıklarında yaşanan değişimin incelenmesi gerekliliğini doğurmuştur.

Mağazadan satın alma davranışı ana akım yaklaşım olmakla birlikte, ürünü mağazada yakından görüp inceleyen tüketiciler, internet bağlantısı olan mobil araçları kullanarak benzer ürünler arasında özellik ve fiyat karşılaştırması yaparak, ürünü internet üzerinden satın almayı tercih edebilmektedir. Bununla birlikte, e-alışverişin risklerini neden olarak göstererek bundan kaçınan fakat internetin sunduğu avantajların farkında olan bazı tüketiciler ise satın almayı mağaza içinde gerçekleştirseler bile özellikle ürün ve fiyat bilgisi edinmek ve karşılaştırma yapmak amacıyla 'Interneti' kullanmakta, satın alma sürecinin araştırma aşamasını online ortamda, satın alma aşamasını ise mağaza içinde gerçekleştirerek, farklı bir yaklaşım da benimseyebilmektedirler.

Yeni ekonomi tanımına temel teşkil eden 'internet'in tüketici davranışlarına yansımaları, stratejik önem arz eden bir pazarlama konusu olmaktadır. Bu bağlamda çalışmanın amacı; tüketicilerin e-alışveriş davranışlarının belirlenmesi ve Internet'in satın alma karar sürecinin hangi aşamasında daha yoğun olarak kullanıldığının tespit edilmesidir. Bununla birlikte internetten ve mağazadan alışveriş yapan tüketicilerin demografik özellikler açısından ve alışverişe bakış açıları açısından karşılaştırılmaları da amaçlanmaktadır.

\section{LITERATÜR INCELEMESi}

Bilgi teknolojilerine dayalı yeni ekonomik ilişkilerin, yeni iş alanlarının oluşması ve mevcut iş alanlarının yeni iletişim kanallarının kullanılması ile tekrar şekillenmesi olarak tanımlanan yeni ekonominin ortaya çıkmasıyla birlikte, geleneksel iş modellerinin yerini bilgi ve iletişim teknolojilerine dayalı modeller almaya başlamıştır (Barışık, Yirmibeşçik, 2006: 40). Yeni ekonominin savunucuları insanların elleri ile değil beyinleri ile çalıştıkları bir dünyadan bahsetmektedirler (Rimmel, Diedrich, 2000). Küreselleşmenin güçlenmesine katkı sağlayan bilgi ve iletişim teknolojileri, yeni ekonominin itici gücü olarak önemli bir rol oynamaktadır. Özellikle İnternetin ortaya çıkışıyla birlikte sınırlar önemini yitirmiş, küreselleşme çok uluslu büyük işletmelerle sınırlı kalmamış ve küçük işletmelerin iş dünyasında önemli birer oyuncu olmalarının önü açılmış, geleneksel yöntemlerle yapılan ticaret de elektronik ortama taşınmaya başlamıştır (izgi, Şahin, 2013; Rimmel, Diedrich, 2000). 1960'ların ortasında bankaların EFT (elektronik fon transferi) faaliyetleri ile birlikte hayatımıza giren elektronik ticaret (eticaret) kavramı (Schneider, 2014: 9), mal ve hizmetlerin dağıtım, pazarlama, satı̧̧ ve teslimatının Internet ve diğer bilgisayar ağları gibi elektronik sistemler üzerinden gerçekleştirilmesini kapsamaktadır (ITC, 2009: 12). Genel olarak işletmeler arasında (B2B) gerçekleşen ve tüketiciler arasında (B2C) gerçekleşen e-ticaret kavramı, özellikle bilgisayar ve Internetin hanelere girmesiyle birlikte pazarlama ve özellikle tüketici davranışı çalışmalarının konusu haline gelmiştir.

Internetin en çok etkilediği alanlardan biri pazarlamadır. Alanda, elektronik mağaza, elektronik perakendecilik, alışveriş siteleri gibi kavramların ortaya çıkmasına neden olan Internetin ticaret kapsamında değerlendirilmesi ile birlikte Internet üzerinden alışveriş kavramı literatüre girmiştir. Internet üzerinden alışveriş (online alışveriş, e-alışveriş), e-ticaretin işletme ve tüketici (B2C) arasında gerçekleştirilen boyutu ile ilgili olup, tüketicilerin internet (web siteleri) üzerinden her türlü mal veya hizmete ulaşması, mal/hizmet hakkında bilgi edinmesi, rakip firmalarla kıyaslama yapabilmesi, elektronik ödeme, elektronik bankacılık ve sigortacılık, danışmanlık işlemler gibi faaliyetleri yapabilmesidir (Amağan, Turan, 2014:2). Mağazadan alışverişe kıyasla Internet üzerinden alışverişin sunduğu gece gündüz erişilebilir olma, benzer ürünlerin kolayca kıyaslanabilmesi, enerji tasarrufu gibi kolaylıklar (Kaufman-Scarborough, Lindquist, 2002:335) e-alışverişin benimsenmesini ve yaygınlaşmasını sağlamaktadır. Bununla birlikte detaylı ürün bilgisine ulaşabilme ve ürün çeşitliliği internet üzerinden alışverişi tüketiciler için çekici kılan diğer özelliklerdir (Enginkaya, 2006: 12)

Internet, tüketicilerin mal-hizmet satın alma şekillerini, tercihlerini ve tutumlarını etkilemektedir (Alba, Lynch, Weitz vd. 1987; Forsythe, Shi, 2003; Soopramanien, Robertson, 2007; İzgi, Şahin, 2013). Aslında, tüketiciler teknolojinin kendisinden çok Internetin alışveriş deneyimini nasıl geliştirebildiği ve neticede daha iyi kararlar vermelerine katkıda bulunup bulunmadığı ile ilgilenmektedirler (Burke, 2002). Bu bağlamda değerlendirildiğinde, Internetin sadece ürünün satın alınması aşamasında değil satın alma karar sürecinin diğer aşamalarında da kullanıldığı söylenebilir. Başka bir ifadeyle, Internet üzerinden alışverişi benimsemeyen tüketiciler bile satın alma karar sürecinin bilgi araştırma ve alternatifleri değerlendirme aşamalarında (Curtis, 2000) Internetin sunduğu avantajlardan faydalanma yoluna gitmektedirler. Buna göre bu grupta yer alan tüketiciler, Interneti sadece ürün ile ilgili bilgileri edinmek için kullanıp, ürünü mağazadan satın almayı tercih etmektedirler. Bu bakımdan, ürün satın alma kararının yanı sıra, kişinin bilgi edinme ihtiyacını en iyi şekilde karşılayacak alışveriş aracını (iletişim aracını) seçmesi de oldukça önemlidir (Chiang, Dholakia, 2003). 
İnternet üzerinden yapılan alışveriş rakamlarındaki artışa rağmen dönüşüm oranının (ziyaretçilerin müşteriye dönüşme oranı) istenilen düzeyde olmamasından şikayet eden perakendecilerin endişelerine değinen Moe ve Fader (2004), bu oranın düşüklüğünü, bir ürünle ilgili Internet üzerinden yapılan araştırmanın geleneksel yollarla yapılan araştırmadan daha düşük maliyetli olması ile ilişkilendirmişlerdir. Bununla birlikte işletmenin web sitesini inceleyip İnternet üzerinden alışveriş yapmayan tüketicilerin akabinde ürünü mağazadan satın alma olasılığı göz önünde bulundurulduğunda (Soopramanien, Robertson, 2007) dönüşüm oranının istenilen düzeyde olmamasının işletmeler için çok da sıkıntılı bir durum olmadığı söylenebilir. Bu noktada, özellikle çoklu kanallardan pazarlama stratejisini benimseyen işletmelerin, Internet sayfalarını ziyaret eden tüketicilerin farklı davranış tiplerini, özel ihtiyaçlarını, beklenti ve endişelerini anlamaları, sayfalarını ve alışveriş süreçlerini de buna göre düzenlemelerinin rekabet avantajı sağlayacağı söylenebilir. Bu bağlamda tüketicileri, Interneti satın alma karar sürecinin hangi aşamasında (bilgi araştırma veya satın alma) kullandıkları bilgisine göre bölümlendirip incelemek faydalı olabilir. Örneğin, mağaza içi alışverişi tercih eden ama araştırma aşamasını sanal ortamda gerçekleştiren tüketicileri sanal ortamda alışverişe teşvik etmek için farklı, araştırma aşamasını da geleneksel yöntemlerle yapmayı tercih eden tüketicileri teşvik etmek için farklı stratejiler geliştirilmesi uygun olur.

Türkiye İstatistik Kurumu'nun 2015 yılında gerçekleştirdiği Hane halkı Bilişim Teknolojileri Kullanım Araştırması (TUIK, 2015) sonuçlarına göre ülkemizde internet erişimi sağlayanların oranı \%55,9 olup, her beş kişiden biri İnternet üzerinden alışveriş yapmaktadır. Her geçen yıl artan kullanım oranları ile paralel olarak ülkemizde, tüketicilerin Internet üzerinden alışverişe yönelik tutumlarının, bu kişilerin demografik özelliklerinin ve davranışlarını etkileyen faktörlerin belirlenmesine yönelik çalışmaların (Özgüven, 2011; İzgi, Şahin, 2013; Mürütsoy, 2013; Armağan, Turan, 2014; İ̧̧ler, Yarangümelioğlu, Gümülü, 2014) sayısı da artmaktadır. Bu çalışmada önceki çalışmalardan farklı olarak tüketicilerin Internet üzerinden bilgi araştırma davranışının da ayrı bir değişken olarak ele alınmış olup İnternet'in satın alma karar sürecinin hangi aşamasında daha yoğun olarak kullanıldığının belirlenmesine çalışılmıştır.

\section{VERI VE YÖNTEM}

Bu araştırmada ele alınan temel konu, tüketicilerin Internet üzerinden alışveriş ve araştırma davranışlarının, demografik özelliklerinin ve farklııklarının ortaya konulması olup, çalışma bu yönüyle betimleyici bir araştırmadır. Analize tabi tutulacak verileri toplamak için anket tekniği kullanılmıştır. Literatürde yer alan çalışmalardan (Kaufman-Scarborough, Lindquist, 2002; Soopramanien, Robertson, 2007) yola çıkılarak hazırlanan soru kağıdında, Internetten alışveriş yapma sıklığı, alışveriş öncesinde İnternetten araştırma yapma sıklığı, günlük olarak internette harcanan süre, İnternetin hangi araçlar üzerinden ne sıklıkla kullanıldığı, Internet alışverişte hangi arayüzün tercih edildiği gibi tanımlayıcı sorular bulunmaktadır. Bunun yanı sıra, İnterneti kullanma amaçlarının önem düzeyine göre sıralanması istenerek alışveriş amacının hangi sırada yer aldığı da belirlenmeye çalışılmıştır. Alışveriş öncesinde İnternet üzerinden hangi tür bilgilerin araştırıldığı (http://blog.fieldagent.net/omnichannel-special-the-webrooming-phenomenon-beyond-survey), hangi ürün grupları için (https://www.statista.com/statistics/589700/share-consumers-showroom-canada-category/) Internet üzerinde alışverişin ve araştırmanın yapıldığı ve demografik özellikler (cinsiyet, yaş, gelir, eğitim durumu) da sorulan sorular arasında yer almıştır.

Çalışmanın evrenini Ankara'da yaşayan tüketiciler oluşturmakta olup, veriler oluşturulan anket formu aracılığıyla, kolayda örneklem yöntem ile ulaşılan katılımcılardan toplanmıştır. Sahada 364 adet anket uygulanmış olup 340 adet kullanılabilir anket elde edilmiştir. Daha önce İnternetten alışveriş yapmamış kişilerin de en azından bilgi araştırma kısmında (alternatiflerin belirlenmesi, ürün bilgisinin araştırılması, kullanıcı yorumlarının incelenmesi gibi) İnternetten faydalanabileceği düşüncesi ile sadece e-alışveriş yapanlara değil, daha önce bu deneyimi yaşamamış olan tüketicilere de ulaşılmaya çalışımışır.

\section{BULGULAR VE TARTIŞMA}

Katılımcıların cinsiyet, yaş, aile geliri ve eğitim durumlarını gösteren bilgiler Tablo 1'de sunulmuştur. Buna göre katılımcıların cinsiyet açııından homojen dağıldı̆̆ı söylenebilir. 18-29 yaş aralığındaki katılımcıların örneklemin yarısını teşkil ettiği, katılımcıların yaklaşık \%56'sının önlisans-lisans mezunu olduğu görülmektedir. Gelir açısından bakıldığında ise katılımcıların yarısından fazlasının 4101 TL ve üzerinde aile gelirine sahip oldukları söylenebilir. Internet üzerinden daha önce alışveriş yaptığını ifade edenlerin oranının yüksek olması (yaklaşık \%87), e-alışverişin ülkemizde gittikçe yaygınlaştığı bilgisi ile paralel bir bulgudur. E-alışveriş yapma oranı, ülkemizde gerçekleştirilen geçmiş çalışmalarda (Aksoy, 2006; Usta, 2006; Armağan, Turan, 2014) elde edilen sonuçlara kıyasla oldukça yüksektir. 
Tablo 1: Katılımcıların Demografik Özellikleri

\begin{tabular}{|c|c|c|c|c|c|c|c|}
\hline & & $\begin{array}{l}\text { Sıklık } \\
\text { (f) }\end{array}$ & $\begin{array}{c}\text { Yüzde } \\
\text { (\%) }\end{array}$ & $\begin{array}{l}\text { Sıklık } \\
\text { (f) }\end{array}$ & $\begin{array}{c}\text { Yüzde } \\
(\%)\end{array}$ & & \\
\hline \multirow{2}{*}{ Cinsiyet } & Kadın & 169 & 49,7 & 8 & 2,4 & 1300 TL ve altı & \multirow{6}{*}{ Aile geliri } \\
\hline & Erkek & 171 & 50,3 & 30 & 8,8 & $1301-2000 \mathrm{TL}$ & \\
\hline \multirow{3}{*}{ Yaş } & $18-29$ & 175 & 51,5 & 29 & 8,5 & $2001-2700 \mathrm{TL}$ & \\
\hline & $30-44$ & 113 & 33,2 & 35 & 10,3 & $2701-3400 \mathrm{TL}$ & \\
\hline & $45-60$ & 52 & 15,3 & 50 & 14,7 & $3401-4100 \mathrm{TL}$ & \\
\hline \multirow{4}{*}{$\begin{array}{l}\text { Eğitim } \\
\text { durumu }\end{array}$} & Lise & 76 & 22,4 & 188 & 55,3 & 4101 TL ve üstü & \\
\hline & Önlisans- Lisans & 191 & 56,2 & 294 & 86,5 & Evet & \multirow{2}{*}{$\begin{array}{l}\text { Internet } \\
\text { alışverişi } \\
\end{array}$} \\
\hline & Lisansüstü & 73 & 21,5 & 46 & 13,5 & Hayır & \\
\hline & Toplam & 340 & 100,0 & 340 & 100,0 & Toplam & \\
\hline
\end{tabular}

Daha önce Internet üzerinden alışveriş yaptığını belirten katılımcıların $(n=294)$ yaklaşık \%38'i yılda birkaç kez, \%33'ü ise ayda birkaç kez Internet üzerinden alışveriş yaptıklarını belirtmişlerdir (Tablo 2).

Tablo 2: Internet Üzerinden Alışveriş Yapma Sıklığı

\begin{tabular}{|l|c|c|}
\cline { 2 - 3 } \multicolumn{1}{c|}{} & Sıklık (f) & Yüzde (\%) \\
\hline Nadiren & 63 & 21,4 \\
\hline Yılda birkaç kez & 112 & 38,1 \\
\hline Ayda birkaç kez & 98 & 33,3 \\
\hline Haftada birkaç kez & 18 & 6,1 \\
\hline Her gün & 3 & 1,0 \\
\hline Toplam & 294 & 100,0 \\
\hline
\end{tabular}

Katılımcılara 2015 Webrazzi (http://webrazzi.com/2016/01/11/iste-webrazzi-odulleri-2015-kazananlari/) sonuçlarına göre Türkiye'nin en çok kullanılan alışveriş sitelerinin yer aldığı bir liste verilerek en çok hangilerini kullandıklarını belirtmeleri söylenmiştir. Markaların kendi sayfalarının da tercih edilebileceği düşüncesiyle listeye markaların resmi sayfaları seçeneği ve bireylerin özellikle tercih ettikleri ama listede yer almayan siteleri yazabilmeleri için de "Diğer" başlığı eklenmiştir. Buna göre en sık kullanılan siteler sırasıyla "hepsiburada.com", "trendyol.com" ve "n11.com" olurken, dördüncü sırada markaların kendi siteleri yer almıştır. "Diğer" başlı̆ı altında en çok belirtilen sayfalar "aliexpress.com" ve "dr.com.tr" ve "idefix.com" olmuştur.

Tablo 3: En Çok Kullanılan Alışveriş Siteleri

\begin{tabular}{|l|c|c|}
\hline & Sıklık (f) & Yüzde (\%) \\
\hline hepsiburada.com & 121 & 41,2 \\
\hline Trendyol.com & 106 & 36,1 \\
\hline n11.com & 93 & 31,6 \\
\hline Markaların resmi web sayfaları & 84 & 28,6 \\
\hline gittigidiyor.com & 68 & 23,1 \\
\hline sahibinden.com & 64 & 21,8 \\
\hline markafoni.com & 63 & 21,4 \\
\hline morhipo.com & 50 & 17,0 \\
\hline
\end{tabular}

Online alışveriş yapan katılımcılara, alternatif erişim seçeneklerinden hangilerini tercih ettikleri de sorulmuş olup katılımcıların büyük bir kısmının alışveriş yaptıkları sitenin orijinal internet sayfası görünümünü tercih ettikleri, sadece \%17'lik kesimin sitelerin telefon uygulamalarını (app) kullanmayı seçtiği belirlenmiştir. Bu sonucun, özellikle, ürünlerini cep telefonu üuygulamaları üzerinden satmak için tüketicileri bu kanala yönlendiren işletmeler tarafından dikkate alınması faydalı olabilir. Uygulamaların kullanıcı dostu hale getirilerek iyileştirilmesi tüketicilerin isteksizliğini gidermek için bir yol olabilir.

Tablo 4: Online Alışveriş Yaparken Tercih Edilen Format

\begin{tabular}{|l|c|c|}
\hline & Sıklık (f) & Yüzde (\%) \\
\hline Alışveriş sitesinin orijinal internet sayfası & 235 & 79,9 \\
\hline Mobil görünümlü sayfa & 24 & 8,2 \\
\hline Sitenin mobil uygulaması & 51 & 17,3 \\
\hline
\end{tabular}


Katılımcıların alışveriş yapmadan önce Internet üzerinden araştırma sıklıklarını gösteren Tablo 5 incelendiğinde, genel olarak örneklemin çoğunluğunun en az ayda birkaç kez araştırma yaptığı görülmektedir. Internet üzerinden alışveriş yapanlar ele alındığında, katılımcıların yaklaşık \%39'unun en az haftada birkaç kez araştırma yaptıkları söylenebilir. Internet üzerinden alışveriş yapmayanların yaklaşık \%35'i de hiçbir zaman Internet üzerinden araştırma yapmadıklarını ifade etmişlerdir.

Tablo 5: Alışveriş Yapmadan Önce İnternet Üzerinden Araştırma Yapma Sıklığı

\begin{tabular}{|l|c|c|c|c|c|c|}
\hline \multirow{2}{*}{} & \multicolumn{2}{|c|}{$\begin{array}{c}\text { Tüm } \\
\text { Katılımcılar }\end{array}$} & \multicolumn{2}{c|}{$\begin{array}{c}\text { Internetten } \\
\text { Alışveriş Yapanlar }\end{array}$} & \multicolumn{2}{c|}{$\begin{array}{c}\text { Internetten } \\
\text { Alışveriş Yapmayanlar }\end{array}$} \\
\cline { 2 - 7 } & Sıklık (f) & Yüzde (\%) & Sıklık (f) & Yüzde (\%) & Sıklık (f) & Yüzde (\%) \\
\hline Hiçbir zaman & 16 & 4,7 & 0 & 0 & 16 & 34,8 \\
\hline Nadiren & 92 & 27,1 & 74 & 25,2 & 18 & 39,1 \\
\hline Yılda birkaç kez & 35 & 10,3 & 31 & 10,5 & 4 & 8,7 \\
\hline Ayda birkaç kez & 78 & 22,9 & 76 & 25,9 & 2 & 4,3 \\
\hline Haftada birkaç kez & 83 & 24,4 & 81 & 27,6 & 2 & 4,3 \\
\hline Her gün & 36 & 10,6 & 32 & 10,9 & 4 & 8,7 \\
\hline Toplam & 340 & 100,0 & 294 & 100,0 & 46 & 100 \\
\hline
\end{tabular}

Katılımcıların günlük olarak Internette harcadıkları süreyi gösteren Tablo 6 incelendiğinde, genel olarak örneklemin yaklaşık \%39'unun günde en az 3 saatlerini Internette geçirdikleri görülmektedir. Bu oran Internet üzerinden alışveriş yapanlar ele alındı̆̆ında yaklaşık \%42'ye yükselmektedir.

Tablo 6: Internette Günlük Harcanan Süre

\begin{tabular}{|l|c|c|c|c|c|c|}
\hline \multirow{2}{*}{} & \multicolumn{2}{|c|}{$\begin{array}{c}\text { Tüm } \\
\text { Katılımcılar }\end{array}$} & \multicolumn{2}{c|}{$\begin{array}{c}\text { Internetten } \\
\text { Alışveriş Yapanlar }\end{array}$} & \multicolumn{2}{c|}{$\begin{array}{c}\text { Internetten } \\
\text { Alışveriş Yapmayanlar }\end{array}$} \\
\cline { 2 - 7 } & Sıklık (f) & Yüzde (\%) & Sıklık (f) & Yüzde (\%) & Sıklık (f) & Yüzde (\%) \\
\hline 0-1 saat & 41 & 12,1 & 27 & 9,2 & 14 & 30,4 \\
\hline 1-2 saat & 72 & 21,2 & 61 & 20,7 & 11 & 23,9 \\
\hline 2-3 saat & 94 & 27,6 & 83 & 28,2 & 11 & 23,9 \\
\hline 3 saatten fazla & 133 & 39,1 & 123 & 41,8 & 10 & 21,7 \\
\hline Toplam & 340 & 100,0 & 294 & 100,0 & 46 & 100 \\
\hline
\end{tabular}

Çalışmada katıımcılara ayrıca Interneti hangi araçlar üzerinden ne sıklıkla kullandıkları (1=Hiçbir zaman, 5=Her zaman) da sorulmuş, elde edilen veriler Tablo 7'de sunulmuştur. Buna göre katılımcılar, Internet üzerinden alışveriş yapsın yapmasın, en çok cep telefonları aracılığıyla Interneti kullandıklarını ifade etmişlerdir. İkinci sırada dizüstü bilgisayarları yer almaktadır. Bu sonuç, Türkiye'deki tüketiciler için mobil cihazların online alışverişin anahtarı olduğunu ifade eden uluslararası bir çalışmanın bulguları ile birlikte değerlendirildiğinde mobil cihazlar üzerinden alışveriş sürecinin basitleştirilmesi e-ticaret yapan işletmeler için üzerinde durulması gereken bir konu olarak değerlendirilebilir.

Tablo 7: Farklı Araçlar Üzerinden Interneti Kullanma Sıklığı

\begin{tabular}{|c|c|c|c|c|c|c|c|c|c|c|c|c|}
\hline & & \multicolumn{2}{|c|}{$\begin{array}{l}\text { Hiçbir } \\
\text { zaman }\end{array}$} & \multicolumn{2}{|c|}{ Nadiren } & \multicolumn{2}{|c|}{ Bazen } & \multicolumn{2}{|c|}{ Çoğunlukla } & \multicolumn{2}{|c|}{$\begin{array}{c}\text { Her } \\
\text { zaman }\end{array}$} & \multirow[t]{2}{*}{ Ort. } \\
\hline & & $\mathrm{F}$ & $\%$ & $f$ & $\%$ & $f$ & $\%$ & $\mathrm{~F}$ & $\%$ & $f$ & $\%$ & \\
\hline \multirow{4}{*}{$\begin{array}{l}\text { Tüm } \\
\text { Katılımcılar }\end{array}$} & Masaüstü & 132 & 38,8 & 45 & 13,2 & 40 & 11,8 & 74 & 21,8 & 49 & 14,4 & 2,5971 \\
\hline & Dizüstü & 105 & 30,9 & 44 & 12,9 & 62 & 18,2 & 86 & 25,3 & 43 & 12,6 & 2,7588 \\
\hline & Tablet & 194 & 57,1 & 69 & 20,3 & 35 & 10,3 & 33 & 9,7 & 9 & 2,6 & 1,8059 \\
\hline & $\begin{array}{l}\text { Cep } \\
\text { telefonu }\end{array}$ & 46 & 13,5 & 12 & 3,5 & 44 & 12,9 & 88 & 25,9 & 150 & 44,1 & 3,8353 \\
\hline \multirow{4}{*}{$\begin{array}{l}\text { Internetten } \\
\text { Alışveriş } \\
\text { Yapanlar }\end{array}$} & Masaüstü & 109 & 37,1 & 37 & 12,6 & 32 & 10,9 & 69 & 23,5 & 47 & 16,0 & 2,6871 \\
\hline & Dizüstü & 84 & 28,6 & 35 & 11,9 & 57 & 19,4 & 76 & 25,9 & 42 & 14,3 & 2,8537 \\
\hline & Tablet & 161 & 54,8 & 60 & 20,4 & 33 & 11,2 & 32 & 10,9 & 8 & 2,7 & 1,8639 \\
\hline & $\begin{array}{l}\text { Cep } \\
\text { telefonu }\end{array}$ & 39 & 13,3 & 12 & 4,1 & 41 & 13,9 & 75 & 25,5 & 127 & 43,2 & 3,8129 \\
\hline \multirow{4}{*}{$\begin{array}{l}\text { Internetten } \\
\text { Alışveriş } \\
\text { Yapmayanlar }\end{array}$} & Masaüstü & 23 & 50,0 & 8 & 17,4 & 8 & 17,4 & 5 & 10,9 & 2 & 4,3 & 2,0217 \\
\hline & Dizüstü & 21 & 45,7 & 9 & 19,6 & 5 & 10,9 & 10 & 21,7 & 1 & 2,2 & 2,1522 \\
\hline & Tablet & 33 & 71,7 & 9 & 19,6 & 2 & 4,3 & 1 & 2,2 & 1 & 2,2 & 1,4348 \\
\hline & $\begin{array}{l}\text { Cep } \\
\text { telefonu }\end{array}$ & 7 & 15,2 & 0 & 0 & 3 & 6,5 & 13 & 28,3 & 23 & 50,0 & 3,9783 \\
\hline
\end{tabular}


Internetin alışveriş dışı kullanımlarının da dikkate alındığı çalışmada, katıımcıların en çok hangi amaçlarla Interneti kullandığı da belirlenmeye çalışımıştır (Tablo 8). Buna göre Internetin en çok araştırma yapmak amacıyla kullanıldığı tespit edilmiştir. Bunu e-posta okumak/göndermek izlerken, eğlence ve sosyalleşme üçüncü sırada yer almş, alışveriş yapmak ise son sırada değerlendirilmiştir. Internet kullanımının öncelikli amaçlarından biri satın alma davranışı olmamakla birlikte, karar sürecinin bilgi araştırma ve alternatifleri değerlendirme aşamalarını da kapsayacak şekilde araştırma davranışının ilk sırada yer alması önemli bir bulgudur.

Tablo 8: Interneti Kullanma Amaçlarının Önem Düzeylerine Göre Sıralanması

\begin{tabular}{|l|c|c|c|c|c|c|c|c|}
\hline & \multicolumn{9}{|c|}{ Önem derecesi } & \multicolumn{2}{c|}{ Ağırlık } & \multirow{2}{*}{$\begin{array}{l}\text { Önem } \\
\text { sırası }\end{array}$} \\
\cline { 2 - 11 } & $\mathbf{1}$ & $\mathbf{2}$ & $\mathbf{3}$ & $\mathbf{4}$ & $\mathbf{5}$ & Toplam & $\mathbf{\%}$ & 4 \\
\hline İş için & 101 & 38 & 27 & 29 & 23 & 819 & 16,37 & 4 \\
\hline E-posta okumak-göndermek & 35 & 85 & 60 & 65 & 27 & 852 & 17,04 & 2 \\
\hline Eğlence ve sosyalleşme & 86 & 45 & 34 & 35 & 39 & 821 & 16,42 & 3 \\
\hline Kitap-gazete-dergi okumak & 33 & 47 & 59 & 44 & 43 & 661 & 13,22 & 5 \\
\hline Araştırma yapmak & 69 & 68 & 79 & 58 & 28 & 998 & 19,95 & 1 \\
\hline Alışveriş yapmak & 2 & 25 & 31 & 56 & 84 & 399 & 7,98 & 7 \\
\hline Bankacılık işlemleri için & 11 & 26 & 42 & 47 & 72 & 451 & 9,02 & 6 \\
\hline Toplam & 337 & 334 & 332 & 334 & 316 & 5001 & 100 & \\
\hline
\end{tabular}

*Ağırlıklı toplam = " 1 . derece frekansı $\times 5+2$. derece frekansı $\times 4+3$. derece frekans $\times 3+4$. derece frekansı $\times 4+5$. derece frekansı $\times 1$ " şeklinde hesaplanmıştır

Alışveriş öncesinde Internet üzerinden araştırılması olası bilgiler listelenmiş ve katılımcılardan bu bilgilerden hangisi veya hangilerini edinmek amacıyla araştırma yaptıklarını belirtmeleri istenmiştir (Tablo 9). Katılımcıların en çok alacakları ürünün en uygun fiyatlısını bulabilmek için fiyat araştırması yaptıkları, ikinci olarak da ürünü kullananların yorum ve önerilerini okumaya çalıştıkları söylenebilir.

Tablo 9: Internetten Araştırılan Bilginin Türü

\begin{tabular}{|l|c|c|}
\hline & Sıklık (f) & Yüzde (\%) \\
\hline Fiyat bilgisi & 287 & 84,4 \\
\hline Kullanıcı yorum-önerileri & 267 & 78,5 \\
\hline Ürün bilgisi (açılaması) & 224 & 65,9 \\
\hline Temel ürün özellikleri & 176 & 51,8 \\
\hline SSS cevapları & 102 & 30,0 \\
\hline Ürün görselleri-videoları & 172 & 50,6 \\
\hline Teknik talimatlar & 79 & 23,2 \\
\hline
\end{tabular}

Çalışmada belirlenen ürün grupları için katılımcılara Internet üzerinden araştırma yapıp yapmadıkları ve bu ürünleri Internet üzerinden alıp almayacakları da sorulmuş, elde edilen veriler Tablo $10^{\prime}$ da sunulmuştur. Buna göre Internet üzerinden hakkında bilgi araştırması yapılan ürün gruplarının başında elektronik ürünler yer alırken, bunu sırasıyla Kıyafet-Ayakkabı, Seyahat ve Kitap-Dergi-CD kategorileri izlemektedir. Internetten en çok alınan ve/veya alınması düşünülen ürünler ise sırasıyla Kıyafet-Ayakkabı, Kitap-Dergi-CD, Elektronik ürünler ve Seyahat hizmetleri olarak belirlenmiştir. Önceden saptanan bu kategorilerin dışında kalan ürünlerin belirtilmesi için açılan "Diğer" başlığı altında dile getirilen ürünler başında online biletler (otobüs, konser vb.) ve hayvan mamaları gelmektedir.

Tablo 10: Ürün Gruplarına Göre Online Araştırma-Online Alışveriş Yapma Durumu

\begin{tabular}{|c|c|c|c|}
\hline & & Sıklık (f) & Yüzde (\%) \\
\hline \multirow{11}{*}{ 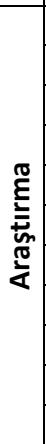 } & Ev aletleri & 156 & 45,9 \\
\hline & Elektronik ürünler & 258 & 75,9 \\
\hline & Otomobil ve aksamı & 95 & 27,9 \\
\hline & Oyun-Oyuncak & 74 & 21,8 \\
\hline & Mobilya & 81 & 23,8 \\
\hline & Spor ürünleri & 105 & 30,9 \\
\hline & Mücevher & 26 & 7,6 \\
\hline & Kıyafet-ayakkabı & 218 & 64,1 \\
\hline & Sağlık-güzellik ürünleri & 119 & 35,0 \\
\hline & Hırdavat ürünleri & 31 & 9,1 \\
\hline & Bitki-bahçe ürünleri & 17 & 5,0 \\
\hline
\end{tabular}

\begin{tabular}{|c|c|c|c|}
\hline & & Sıklık (f) & Yüzde (\%) \\
\hline \multirow{11}{*}{ 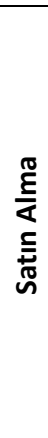 } & Ev aletleri & 113 & 33,2 \\
\hline & Elektronik ürünler & 169 & 49,7 \\
\hline & Otomobil ve aksamı & 49 & 14,4 \\
\hline & Oyun-Oyuncak & 74 & 21,8 \\
\hline & Mobilya & 48 & 14,1 \\
\hline & Spor ürünleri & 82 & 24,1 \\
\hline & Mücevher & 15 & 4,4 \\
\hline & Kıyafet-ayakkabı & 205 & 60,3 \\
\hline & Sağlık-güzellik ürünleri & 98 & 28,8 \\
\hline & Hırdavat ürünleri & 19 & 5,6 \\
\hline & Bitki-bahçe ürünleri & 10 & 2,9 \\
\hline
\end{tabular}




\begin{tabular}{|l|l|c|c|}
\hline GIda & 46 & 13,5 \\
\cline { 2 - 4 } Kitap-dergi-CD & 185 & 54,4 \\
\cline { 2 - 4 } & Seyahat & 186 & 54,7 \\
\hline
\end{tabular}

\begin{tabular}{|l|l|c|c|}
\hline & GIda & 43 & 12,6 \\
\cline { 2 - 4 } & Kitap-dergi-CD & 185 & 54,4 \\
\cline { 2 - 4 } & Seyahat & 151 & 44,4 \\
\hline
\end{tabular}

Son olarak, katılımcıların internetten alışveriş yapma durumu ve sıklığı ile Internet üzerinden araştırma yapma sıklığı bilgileri dikkate alınarak katılımcılar 4 gruba ayrılmıştır. Birinci grup Interneti alışveriş veya araştırma için kullanmayanlar "Internet sevmeyen" tüketicilerden oluşmuştur. İkinci grupta Internetten alışveriş yapmayan ama araştırma yapan kişilerin yer aldığı "Araştırmacılar" grubudur. Üçüncü grupta Interneti araştırma yapmak için kullanan ve düzenli olmasa da (nadiren ve yılda birkaç kez) Internetten alışveriş yapan tüketiciler yer almakta olup bu tüketicilere "Ara sıra alışveriş yapanlar" denilmiştir. Son grup ise Interneti araştırma yapmak için kullanan ve düzenli olarak (en az ayda birkaç kez) alışveriş yapan tüketicilerden oluşmuş olup bu gruba “Internet alışverişçileri” adı verilmiştir. Bu grupların demografik özellikleri Tablo 11'de sunulmuştur.

Tablo 11: Dört Tüketici Grubunun Özellikleri

\begin{tabular}{|c|c|c|c|c|c|}
\hline & & $\begin{array}{c}\text { G1* }^{*} \\
(n=16-\% 4,7)\end{array}$ & $\begin{array}{c}G 2 \\
(n=30-\% 8,8)\end{array}$ & $\begin{array}{c}G 3 \\
(n=175-\% 51,5)\end{array}$ & $\begin{array}{c}\text { G4 } \\
(n=119-\% 35)\end{array}$ \\
\hline \multirow{2}{*}{ Cinsiyet } & Kadın & $6(\% 37,5)$ & $13(\% 43,3)$ & $88(\% 50,3)$ & $62(\% 52,1)$ \\
\hline & Erkek & $10(\% 62,5)$ & $17(\% 56,7)$ & $87(\% 49,7)$ & $57(\% 47,9)$ \\
\hline \multirow{3}{*}{ Yaş } & $18-29$ & $5(\% 31,3)$ & $19(\% 63,3)$ & $88(\% 50,3)$ & $63(\% 52,9)$ \\
\hline & $30-44$ & $4(\% 25,0)$ & $8(\% 26,7)$ & $53(\% 30,3)$ & $48(\% 40,3)$ \\
\hline & $45-60$ & $7(\% 43,8)$ & $3(\% 10,0)$ & $34(\% 19,4)$ & $8(\% 6,7)$ \\
\hline \multirow{3}{*}{ Gelir } & Düşük (<2000) & $4(\% 25,0)$ & $9(\% 30,0)$ & $17(\% 9,7)$ & $8(\% 6,7)$ \\
\hline & Orta(2001-4100) & $7(\% 43,8)$ & $13(\% 43,3)$ & $55(\% 30,9)$ & $40(\% 33,6)$ \\
\hline & Yüksek (4101<) & $5(\% 31,3)$ & $8(\% 26,7)$ & $104(\% 59,4)$ & $71(\% 59,7)$ \\
\hline \multirow{3}{*}{ Eğitim } & Lise & $9(\% 56,3)$ & $9(\% 30,0)$ & $40(\% 22,9)$ & $18(\% 15,1)$ \\
\hline & Önlisans-lisans & $5(\% 31,3)$ & $17(\% 56,7)$ & $101(\% 57,7)$ & $68(\% 57,1)$ \\
\hline & Lisansüstü & $2(\% 12,5)$ & $4(\% 13,3)$ & $34(\% 19,4)$ & $33(\% 27,7)$ \\
\hline \multirow{4}{*}{$\begin{array}{l}\text { Günlük olarak } \\
\text { Internette } \\
\text { harcanan } \\
\text { süre }\end{array}$} & 0-1 saat & $8(\% 50,0)$ & $6(\% 20,0)$ & $20(\% 11,4)$ & $7(\% 5,9)$ \\
\hline & 1-2 saat & $5(\% 31,3)$ & $6(\% 20,0)$ & $37(\% 21,1)$ & $24(\% 20,2)$ \\
\hline & $2-3$ saat & $2(\% 12,5)$ & $9(\% 30,0)$ & $50(\% 28,6)$ & $33(\% 27,7)$ \\
\hline & 3 saatten fazla & $1(\% 6,3)$ & $9(\% 30,0)$ & $68(\% 38,9)$ & $55(\% 46,2)$ \\
\hline Toplam & & $16(\% 100)$ & $30(\% 100)$ & 175 (\%100) & 119(\%100) \\
\hline
\end{tabular}

Tablo 11'de görüldüğü üzere, Internet üzerinden alışveriş yapanlar cinsiyet açısından homojen dağılım göstermekle birlikte e-alışverişi kadınların daha çok tercih ettiği söylenebilir. Bu sonuç, erkeklerin kadınlara göre İnternet üzerinden alışverişe daha meyilli olduğunu ortaya koyan çalışmalardan (Korgaonkar, Wolin, 1999; Emmanouilides and Hammond, 2000; Teo, 2002; Dündar, Yörük, 2009) farklılılık teşkil etmektedir. Bununla birlikte E-alışverişi benimseyenlerin daha çok 18-29 yaş arasındaki, yüksek gelirli, önlisans-lisans mezunu katılımcıların olduğu söylenebilir. Bununla birlikte e-alışveriş yapanların çoğunluğunun günde en az 2 saatlerini Internette harcadıkları söylenebilir. Bu sonuçlar, İnternet alışverişini tercih eden tüketicilerin genç yaşta ve eğitimli kimseler olduğunu gösteren çalışmalarla (i̇zgi, Şahin, 2013) benzerlik göstermektedir.

\section{SONUC}

Bilgi ve dijitalleşmenin ön planda olduğu yeni ekonomik oluşumda e-ticaret yapan işletmelerin ve dolayısıyla internet üzerinden alışveriş yapan tüketicilerin sayısı her geçen gün artmaktadır. Bununla birlikte İnternetin satın alma kararının öncesinde bilgi araştırmak için de kullanılması söz konusudur. Bu açıdan bakıldığında, e-alışverişi, sadece Internet üzerinden $\mathrm{mal} /$ hizmet satın alınması olarak görmemek, satın alma kararını almadan önce ürün ve fiyat bilgisi edinmek, alternatifleri karşılaştırmak, kullanıcıların değerlendirmelerini incelemek için İnternet üzerinden gerçekleştirilen araştırma çabalarını da içerecek şekilde tanımlamak daha bütüncül bir yaklaşım olacaktır.

Tüketicilerin e-alışveriş davranışlarının belirlenmesi amacıyla gerçekleştirilen bu çalışmaya katılanların büyük bir çoğunluğunun (\%87) İnternet üzerinden alışveriş deneyimlerinin olduğu anlaşılmaktadır. Bu oranın, ülkemizde gerçekleştirilen geçmiş çalışmalarda elde edilen sonuçlara kıyasla oldukça yüksek olmasının nedeni Türkiye'de telekomünikasyon alt yapısına yapılan yatırımlar, yeni nesil akıllı cep telefonları ile birlikte internet erişiminin yer ve zaman bağımlılığının azalması ve İnternet üzerinden alışverişin daha güvenli hale gelmesi olabileceği gibi, çoğunluğu, belli aralıklarla 
ziyaret edilen iki alışveriş merkezinin önünde gönüllülük esasına göre ankete cevap veren tüketicilerden oluşan örneklemin farklı alışveriş yöntemlerini denemeye açık olması da olabilir.

Bu çalışmada, erkeklerin kadınlara göre İnternet üzerinden alışverişe daha meyilli olduğunu ortaya koyan çalışmalardan farklı olarak, katıımcılar, Internet üzerinden alışveriş ve araştırma yapma davranışları açısından cinsiyete göre dengeli bir dağııım göstermişlerdir. Bununla birlikte $18-29$ yaş arası gençlerin ve geliri yüksek olanların İnternet üzerinden daha sık alışveriş yaptıkları tespit edilmiştir.

Çalışma sonucunda, tüketicilerin en çok çeşitli ürünlerin ve markaların bir arada sunulduğu online alışveriş siteleri ile markaların kendi resmi sitelerini tercih ettikleri, sayfalara giriş için de telefon uygulamalarından çok alışveriş yapılan sitenin orijinal internet sayfası görünümünün tercih edildiği tespit edilmiştir. İnternet erişimini en çok cep telefonları üzerinden gerçekleştiren katılımcıların, buna rağmen telefon uygulamalarını tercih etmemeleri düşündürücüdür. Bunun nedeni katılımcıların düzenli olarak alışveriş yapmamaları olabileceği gibi, uygulamaların görünüm ve kullanışlılık açısından geleneksel web sayfalarına kıyasla daha olumsuz algılanması olabilir.

Katılımcıların alışveriş yapmadan önce Internet üzerinden araştırma sıklıkları incelendiğinde, genel olarak örneklemin çoğunluğunun en az ayda birkaç kez araştırma yaptığı, Internet üzerinden alışveriş yapanlar ele alındığında ise katılımcıların yaklaşık \%39'unun en az haftada birkaç kez araştırma yaptıkları söylenebilir. Internet üzerinden alışveriş yapmayanlar incelendiğinde bu katılımcıların yaklaşık \%35'inin Internet üzerinden hiç araştırma yapmadığı, \%39'unun ise nadiren araştırma yaptığı tespit edilmiştir. Buna göre Internet üzerinden alışverişi benimsemeyenlerin satın alma aşamasından önce araştırma yaparken de Interneti çok tercih etmedikleri söylenebilir. Internette günlük çok zaman harcamayan bu tüketicilerin e-alışverişten ziyade İnterneti çok benimsememiş oldukları da düşünülebilir. İnternet üzerinden alışveriş yapmayan katılımcıların sayısının oldukça az olduğu düşünüldüğünde bu bulguların ihtiyatlı yorumlanması gerekmektedir.

Internetin en çok hangi amaçlarla kullandığının da araştırıldığı çalışmanın sonucunda, Internetin en çok araştırma yapmak amacıyla kullanıldığı belirlenmiştir. Bunu e-posta okumak/göndermek izlerken, alışveriş en son amaç olarak değerlendirilmiştir. Katılımcıların alışveriş öncesinde ìnternet üzerinden en çok alacakları ürünün en uygun fiyatlısını bulabilmek için fiyat araştırması yaptıkları, ikinci olarak da ürünü kullananların yorum ve önerilerini araştırdıkları tespit edilmiştir. Bu durum, tüketicilerin daha çok tasarruf elde etmek için İnternetten alışverişi tercih ettikleri bulgusu (Chiang, Dholakia, 2003) ile uyumludur.

Internet üzerinden hakkında bilgi araştırması yapılan ürün gruplarının başında elektronik ürünler yer alırken, bunu sırasıyla Kıyafet-Ayakkabı, Seyahat ve Kitap-Dergi-CD kategorileri izlemiştir. Internetten en çok alınan ve/veya alınması düşünülen ürünler ise sırasıyla Kıyafet-Ayakkabı, Kitap-Dergi-CD, Elektronik ürünler ve Seyahat hizmetleri olarak belirlenmiştir. İnternetten alışverişin en önemli avantajları arasında yer alan ürün çeşitliliğinin geniş ve ürünler arası kıyaslamanın kolay olması bu ürün grupları için İnternetin önemli bir alışveriş kanalı olarak kabul edilmesine katkıda bulunmuş olabilir.

Son olarak, internetten alışveriş yapma durumu ve sıklığı ile Internet üzerinden araştırma yapma sıklığı bilgileri dikkate alınarak katılımcılar 4 gruba ayrılmış ve bu grupların karşılaştııılması yapılmaya çalışılmıştır. Buna göre internet üzerinden araştırma ve düzenli olarak alışveriş yapan "Internet alışverişçileri" kategorisinde daha çok 18-29 yaş arasındaki, yüksek gelirli, önlisans-lisans mezunu tüketicilerin yer aldığı, bu kişilerin çoğunluğunun günde en az 2 saatlerini Internette harcadıkları belirlenmiştir. Bu sonuç İnternet alışverişini tercih eden tüketicilerin genç yaşta ve eğitimli kimseler olduğunu gösteren çalışmalarla benzerlik göstermektedir.

Bu çalışma ile İnternet alışverişini tercih eden tüketicilerin profili ve davranışları ortaya koyulmaya çalışılmıştır. İşletmeler İnternet sayfalarını ve dijital ortamda gerçekleştirdikleri faaliyetleri tüketici davranış ve tercihleri doğrultusunda geliştirdikleri takdirde tüketicilerin e-alışverişi benimseme oranının artacağı düşünülmektedir. Çalışmanın bulguları ışığında, İnterneti en çok araştırma yapmak için kullanan tüketicilerin, fiyat karşılaştırmasına imkan veren, detaylı ürün bilgisi sunan, kullanıcı yorum ve önerilerine yer veren, ürün ve marka çeşitliliği fazla olan sayfaları daha çok tercih edecekleri, işletmelerin sayfalarını bu doğrultuda şekillendirmelerinin faydalı olacağı düşünülmektedir.

\section{KAYNAKLAR}

Aksoy, R. (2006). Internet ortamında pazarlama, Seçkin Yayıncılık, Ankara.

Alba, J., Lynch, J., Weitz, B., Janiszewski, C., Lutz, R., Sawyer, A., Wood, S. (1997). Interactive home shopping: consumer, retailer, and manufacturer incentives to participate in electronic marketplaces. The Journal of Marketing, Vol. 61 No. 3, pp. 38-53.

Armağan, E. A., Turan, A. H. (2014). Internet üzerinden alişveriş: demografik faktörlerin, bireysel ihtiyaçlarin etkisi üzerine ampirik bir değerlendirme. Atatürk Üniversitesi İktisadi ve İdari Bilimler Dergisi, 28(3), pp.1-22 
Barışı, S., Yirmibeşçik, O. (2006). Türkiye'de yeni ekonominin oluşum sürecini hızlandırmaya yönelik uyum çabaları. ZKÜ Sosyal Bilimler Dergisi, Cilt 2, Sayı 4, 2006, pp. 39-62

Burke, R.R., 2002. Technology and the customer interface: what consumers want in the physical and virtual store. Journal of the Academy of Marketing Science $30(4)$, pp.411-432.

Chiang, K.P., Dholakia, R.R., 2003. Factors driving consumer intention to shop online. Journal of Consumer Psychology 13 (1), pp. $177-183$.

Curtis, J. (2000). Cars set for online sales boom. Marketing, 10 Feb, pp. $22-23$

Dündar, S., Yörük, D. (2009). Tüketicilerin Internetten alışverişe karşı tutumlarında etkili faktörler. îktisat İşletme ve Finans, 24 (278), pp. $92-$ 109.

Emmanouilides, C., Hammond, K. (2000). Internet usage: Predictors of active users and frequency of use", Journal of Interactive Marketing, Vol. 14 No. 2, pp. 17-32.

Enginkaya, E. (2006). Elektronik perakendecilik ve elektronik alişveriş. Ege Akademik Bakış Dergisi, 6 (1), pp.10-16.

Forsythe, S.M., Shi, B. (2003). Consumer patronage and risk perceptions in Internet shopping. Journal of Business Research 56, pp. 867875.

Iş̧ler, D.B., Yarangümelioğlu, D., Gümülü, E. (2014). Online tüketici satin alma davranişlarini etkileyen faktörlere yönelik bir durum değerlendirmesi: Isparta ilinde bir uygulama. Uluslararası Alanya İşletme Fakültesi Dergisi, 6(3), pp.77-94

ITC(Internatıonal Trade Centre) (2009). Secrets of electronic commerce: A guide for small and medium-sized exporters. 2nd ed. Geneva

İzgi, B. B., Şahin, í. (2013). Elektronik perakende sektörü ve internet alişverişi tüketici davranişi: Türkiye örneği. Muğla Sitki Koçman Üniversitesi Iktisadi Ve Idari Bilimler Fakültesi Ekonomi Ve Yönetim Araştirmalari Dergisi, 2(1), pp. 9-27

Kaufman-Scarborough, C., Lindquist, J.D. (2002). E-shopping in a multiple channel environment. Journal of Consumer Marketing, Vol. 19, No. 4, pp. 333-350

Korgaonkar, P.K., Wolin, L.D. (1999). A multivariate analysis of web page usage. Journal of Advertising Research, Vol. 39 No. 2, pp. 53-68.

Moe, W., Fader, P.S. (2004). Dynamic conversion behaviour at e-commerce sites. Management Science 50 (3), pp. 326-335

Mürütsoy, M. (2013). Internet tüketicisinin satın alma davranişlarinin incelenmesi üzerine bir araştirma. Yayınlanmamış Yüksek Lisans Tezi, Niğde Üniversitesi Sosyal Bilimler Enstitüsü, Niğde

Özgüven, N. (2011). Tüketicilerin online alışverişe karşı tutumları ile demografik özellikleri arasındaki ilişkinin analizi. KMÜ Sosyal ve Ekonomik Araştırmalar Dergisi 13 (21), pp. 47-54

Rimmel, G., Diedrich, A. (2000). E-business and the new economy-A critical perspective, Proceedings of IRIS 23

Schneider, G.P. (2014). Electronic commerce. 11th Edition, Cengage Learning, USA

Soopramanien, D.G.R., Robertson, A. (2007). Adoption and usage of online shopping: An empirical analysis of the characteristics of "buyers" "browsers" and "non-internet shoppers. Journal of Retailing and Consumer Services, 14, pp. 73-82

Teo, T.S.H. (2002). Attitudes toward online shopping and the Internet. Behaviour and Information Technology, 21, pp. $259-271$.

TUIK (2015)- http://www.tuik.gov.tr/PreHaberBultenleri.do?id=18660/erişim tarihi 24.03.2017

Usta, R. (2006). Tüketicilerin demografik özellikleri ve internetten satın alma davranışı üzerine bir araştırma. Kooperatifçilik, 41 (3), pp. 113.

http://blog.fieldagent.net/omnichannel-special-the-webrooming-phenomenon-beyond-survey

http://webrazzi.com/2016/01/11/iste-webrazzi-odulleri-2015-kazananlari/

https://www.statista.com/statistics/589700/share-consumers-showroom-canada-category/ 